\title{
Regional scale cropping systems management options in Telangana using WorldClim data
}

\author{
MANORANJAN KUMAR ${ }^{*}$, K.S. REDDY and K. SAMMI REDDY \\ Division of Resource Management, ICAR-Central Research Institute for Dryland Agriculture, Santosh Nagar, Hyderabad, \\ Telangana - 500059 \\ "Corresponding author: manocrida75@gmail.com
}

\begin{abstract}
ABSTARCT
The present study evaluates the existing district-wise cropping system of Kharif and Rabi season prevailing in Telangana State of India. In kharif season, it was observed that all districts of the states are water surplus and whereas during Rabi season all districts become water deficit. In order to enhance the agricultural production and agricultural based rural economy, alternate cropping system were suggested. Due consideration was given to the existing water resource and farming practices prevailing in the respective district. Re-appropriation of area under various crops was suggested for two scenarios namely, 'A' and ' $B$ ', aimed for reduction in crop water requirement by $10 \%$ and $20 \%$, respectively. In scenario ' $A$ ', it was suggested to reduce the area under transplanted paddy and ground nut by half and $40 \%$ respectively,in kharif season and substantial enhancement in the area under redgram. For rabi season the area under transplanted paddy could be reduced to half for scope to double the area under oilseed. The scenario ' $B$ ' however is feasible in 3 districts, suggests restricting the area under groundnut to comprehensive increase in pulse area. For rabi in scenario ' $\mathrm{B}$ ', it is recommended to further reduce the area under oilseed, paddy and other crops allows more crop diversity including millets, sorghum and caster. The economic analysis suggested that the alternate scenario has the potential to significantly improve the benefit cost ratio apart from enhancement in water productivity.
\end{abstract}

Key words: Dryland farming, water management, crop diversity, rainfed agriculture, composite crop coefficient

Rainfed agriculture in India practiced in $76 \mathrm{mHa}$ area which contributes $44 \%$ to the national food basket providing food to $40 \%$ population (Sharma, 2011) and supports 80 and $60 \%$ of horticulture and livestock respectively. The agricultural production system under rainfed conditions, primarily depending on climatic parameters that includes rainfall, temperature, humidity, solar radiation etc. among which rainfall is considered as the most critical input resources. The significant variation in rainfall over space and time coupled with erratic distribution with higher coefficient of variation adversely affects the sustainability of rainfed agricultural production system (Cooper et al., 2008). The deleterious effect of climate change on agriculture makes farming more vulnerable. Rainwater management assumes major role in achieving resilience in agriculture and thus sustainability in food production (Bastakoti et al., 2016). For effective rainwater management, crop planning based on water budget is most important (Singh et al., 2019).

Rainfall variation in South-West monsoon - kharif season particularly, causing instability in kharif crop production. Two third of the geographical area in India, is prone to drought of varying degrees to the extent of acute drought due to variation in rainfall distribution (Gupta et al. 2011). The increased frequency on extreme events of flood and drought has the potential to reduce more than $20 \%$ of crop net revenue. CRIDA, 2013 develop Vulnerability Index (Rama Rao et al., 2013) considering comprehensive indicators ranging from climate, soil, crop and socioeconomics.

In rainfed agriculture, water is usually a limiting factor due to climatic conditions and so the yield potential is significantly low. Srinivasarao et al.(2015) estimated the potential yield and yield gap of major rainfed crops and cited the mid-season drought and weather aberrations are major reason. Paydar and Qureshi (2012) suggested adjustable mechanism for rainwater management to address the uncertain and dynamic sets of climate change impact and socio-economic conditions. This include facilitating stakeholders with quantitative and qualitative information on the uncertainty characteristics of management verticals derived from climate change impact forecasts (Brekke et al., 
2004, Rao and Punia, 2011; Ruane et al., 2013). It is important to adopt appropriate planning and mitigation measures to address the adverse impact of climate change (Raje and Mujumdar, 2010) and these impacts must be considered when making long-term planning and management decisions (Kadaliya et al., 2015). Pramod et al., 2018 projected the irrigation water requirement for the wheat growing district based on NorESM1-M model of CMIP5 combined with RCP4.5.

South Central India facing an acute water crisis leading to fall in groundwater critically (Reddy et al., 2015). The demand-based water management systems focus to reduce the gaps between supplies and demands and thus the water use efficiency increases (Raoand Rajput, 2009). Water requirement of various crops in the cropping system is an important aspect in optimizing water resources in enhancing water productivity and tradeoff between total production and productivity. The cropping system that includes rainfed crops may be more efficient in view of water productivity but may result in lower production. The sustainable cropping system is utmost important to assess the adaptive capabilities of water resources development under paradigm shift in climate conditions as well as socio-economic.

In view of above, this study was undertaken with the objective to evaluate the existing crops and cropping system with respect to water use efficiency and suggest change in cropping system to further enhance the rain water productivity as well rural economy and livelihood.

\section{MATERIALS AND METHODS}

\section{Study area}

The state of Telangana is bounded by $17^{\circ} 07^{\prime}$ Nand $79^{\circ} 12^{\prime}$ Eand spread over $11.2 \mathrm{mha}$ area and mostly fall into deccan plateau agro-ecosystem which is hot-moist semiarid. The regionreceives $80 \%$ and $20 \%$ of annual rainfall during Kharif and Rabi, respectively resulting into $120 \%$ cropping intensity Broadly. Telangana is divided into two agro-ecological regions namely, Northern Telangana zone and Southern Telangana zone. The typical characteristics of these regions are provided in table 1 .

\section{Data}

The monthly average rainfall data layer of both the seasons was obtained from WorldClim global climate data (Hijmans et al., 2005) for 1950-2000 periods. These data are extensively used in several studies on spatial modeling particularly in investigating impact of Clean Development
Mechanism - Afforestation/Reforestation (CDM-AR) on different ecological parameters (Trabucco et al., 2008; Zomer et al., 2007; 2008, Rodrigo et al., 2010; Jones and Thronton, 2012; Donink et al., 2014; Yagini and Panos, 2016). Global-PET, a grid based spatially distributed potential evapotranspiraton (Hargreaves et al., 1985) was also obtained as open source data for year 2014-15. The district-wise crop data and other agricultural information for year 2014-15 were collected from the various publications on agricultural statistics from different government departments. However, the relevant complete set of data including exclusive water resources data for Nizamabad district was not available and thus is not included in the study.

\section{Methodology}

Three major crops under irrigated and rainfed conditions were identified for kharif and Rabi for each district. All data were converged in the GIS environment (ArcInfo 9.3) to perform climatic water balance. The respective district and state shapefile were superimposed to the rainfall and PET data and accordingly data was extracted. These extracted data were then interacted using mathematical operator to determine the deficit and surplus district based on seasonal rainfall and PET.

\section{Computation of composite crop coefficient, $K$}

The composite crop coefficients were computed to address the issue of different crop coefficient of crops in the season. This was done to bring a unique crop coefficient values to simplify the analysis for water use efficiency. The computation was done in such a way that, the crop under more area has more bias in composite crop coefficient. This was computed using the following formula for weighted mean.

$$
K=\frac{\sum K c_{i} \times A_{i}}{\sum A_{i}}
$$

Where, $K$ is composite crop coefficient, $K c_{i}$ is crop coefficient of crop $i, A_{i}$ is area under crop

The average seasonal crop coefficient, Kc values, adopted from FAO-56 (Allen et al., 1998). Cropping system having composite crop coefficient of 0.65 is considered as the most water efficient cropping system.

It is hypothesized that the improvement in the rainwater water use efficiency could be achieved by reallocating the areas under different crop by reverse 
Table 1: Agro-ecological characteristics of different regions of Telangana

\begin{tabular}{|c|c|c|c|c|c|c|}
\hline $\begin{array}{l}\text { Agro-ecological } \\
\text { region }\end{array}$ & Districts & Climate & $\begin{array}{l}\text { Prevailing } \\
\text { Soil type }\end{array}$ & $\begin{array}{l}\text { Annual } \\
\text { rainfall } \\
(\mathrm{mm})\end{array}$ & $\begin{array}{l}\text { Agricultur } \\
\text { Net sown } \\
\text { area } \\
(, 000 \text { ha })\end{array}$ & $\begin{array}{l}\text { duse } \\
\text { Cropping } \\
\text { intensity }(\%)\end{array}$ \\
\hline $\begin{array}{l}\text { North } \\
\text { Telangana zone }\end{array}$ & $\begin{array}{l}\text { Adilabad } \\
\text { Khammam } \\
\text { Karimnagar } \\
\text { Warangal } \\
\text { Nizamabad }\end{array}$ & Semi-arid & $\begin{array}{l}\text { Black soil } \\
(56.0 \%) \\
\text { Red soil } \\
(28.3 \%)\end{array}$ & $\begin{array}{l}800- \\
1050\end{array}$ & 2455 & 125.7 \\
\hline $\begin{array}{l}\text { Southern } \\
\text { Telangana zone }\end{array}$ & $\begin{array}{l}\text { Mahbubnagar } \\
\text { Medak } \\
\text { Nalgonda } \\
\text { Rangareddy }\end{array}$ & Semi-arid & $\begin{array}{l}\text { Red soil } \\
(46.1 \%) \\
\text { Sandy loam } \\
(24.1 \%)\end{array}$ & $\begin{array}{l}700- \\
840\end{array}$ & 1818 & 112.7 \\
\hline
\end{tabular}

Table 2: Composite crop coefficient, Ks, computed for existing, scenario A and scenario B

\begin{tabular}{|c|c|c|c|c|c|c|c|c|}
\hline \multirow[t]{2}{*}{ District } & \multicolumn{4}{|c|}{ Composite crop coefficient, $\mathrm{K}$, kharif } & \multicolumn{4}{|c|}{ Composite crop coefficient, K, rabi } \\
\hline & Area & Existing & Scenario A & Scenario B & Area & Existing & Scenario A & Scenario B \\
\hline Adilabad & 485 & 0.83 & 0.74 & 0.66 & 77.9 & 0.65 & $0.58^{*}$ & $0.52^{*}$ \\
\hline Karimnagar & 336.6 & 0.91 & 0.82 & 0.72 & 131.4 & 0.93 & 0.83 & 0.74 \\
\hline Khammam & 335.5 & 0.91 & 0.82 & 0.73 & 58.8 & 0.89 & 0.80 & 0.71 \\
\hline Mahbubnagar & 499 & 0.80 & 0.72 & $0.64^{*}$ & 396 & 0.80 & 0.72 & $0.64^{*}$ \\
\hline Medak & 269 & 0.82 & 0.74 & 0.66 & 115.2 & 0.75 & 0.68 & $0.60^{*}$ \\
\hline Nalgonda & 390 & 0.85 & 0.77 & 0.68 & 164.3 & 0.97 & 0.87 & 0.78 \\
\hline Rangareddy & 84.7 & 0.79 & 0.71 & $0.63^{*}$ & 33 & 0.79 & 0.71 & $0.64^{*}$ \\
\hline Warangal & 341 & 0.89 & 0.80 & 0.71 & 46 & 0.72 & 0.65 & $0.58^{*}$ \\
\hline
\end{tabular}

* Corresponding scenario is not feasible

calculation using the reduction the composite $\mathrm{K}$. Two scenarios i.e. A and B are considered in which composite $\mathrm{K}$ is reduced by $10 \%$ and $20 \%$, respectively but not less than 0.65 . The computed composite crop coefficient for different scenario is given in Table 2. Accordingly, ETc calculated for $\mathrm{K}$ and superimposed with seasonal rainfall to identify surplus and deficit district for different scenario. These resultant data thus obtained was corroborated with the existing water resource available in the district (Table 3) and after considering these, alternate cropping system were suggested.

\section{Economic analysis}

Economic analysis was performed for three parameters namely, cost of cultivation, return and benefit:cost (B:C) ratio for existing cropping system as well as for scenario $\mathrm{A}$ and $\mathrm{B}$. These 3 economic parameters were computed for all 8 districts for Kharif as well as Rabi season. For computing various parameters, the prevailing rate of various agricultural input and output for year 2018-19 were taken in to the consideration. The cost of cultivation was computed using A2+FL formula as suggested by commission for agricultural cost and price (CACP). A2 includes all the paid-up actual cost in purchase of all inputs including seed, fertilizers, chemicals, hiring labour, machinery and services as well as leased-in land. FL components includes the family labour in monetary terms. Returns were computed from the prevailing MSP of the crops. The B:C ratio was determinized using the following equation

$$
B: C=\frac{\sum A_{i} \times R_{i}}{\sum A_{i} X C_{i}} \ldots
$$

Where, $\mathrm{B}: \mathrm{C}$ is $\mathrm{B}: \mathrm{C}$ ratio, $\mathrm{A}_{\mathrm{i}}, \mathrm{R}_{\mathrm{i}}$ and $\mathrm{C}_{\mathrm{i}}$ are area, return $\left(\right.$ Rsha $\left.^{-1}\right)$ and cost $\left(\right.$ Rsha $\left.^{-1}\right)$ for $i^{\text {th }}$ crop, respectively. 
Table 3: District wise existing water resources and utilization in agriculture (Telangana)

\begin{tabular}{lrrrrr}
\hline \multicolumn{7}{c}{ Area irrigated $^{2}$} \\
\hline District & $\begin{array}{r}\text { Annual } \\
\text { Rainfall }\end{array}$ & $\begin{array}{r}\text { Net sown } \\
\text { area }(, 000 \text { ha })^{1}\end{array}$ & $\begin{array}{r}\text { Ground water } \\
\text { resources }\end{array}$ & $\begin{array}{r}\text { Surface water } \\
\text { resources }\end{array}$ & $\begin{array}{r}\text { Cropping } \\
\text { intensity }(\%)^{3}\end{array}$ \\
\hline Adilabad & 1053 & 552 & 86.6 & 27.5 & 115 \\
Karimnagar & 920 & 454 & 314.2 & 61.1 & 128 \\
Khammam & 1059 & 382 & 101.8 & 68.9 & 109 \\
Mahbubnagar & 692 & 836 & 196.3 & 30.8 & 108 \\
Medak & 1001 & 457 & 211.6 & 5.6 & 116 \\
Nalgonda & 753 & 571 & 268.8 & 5.1 & 117 \\
Rangareddy & 838 & 209 & 74.9 & 84.2 & 111 \\
Warangal & 1059 & 492 & 276.5 & 5.8 & 126 \\
\hline
\end{tabular}

${ }^{1}$ Agricultural Statistics at a Glance 2015-16, Directorate of Economics and Statistics, Government of Telangana.

${ }^{2} 5$ th minor irrigation census, reference year 2013-14.

${ }^{3}$ Derived from the data presented in Agricultural Statistics at a Glance 2015-16, Directorate of Economics and Statistics, Government of Telangana.
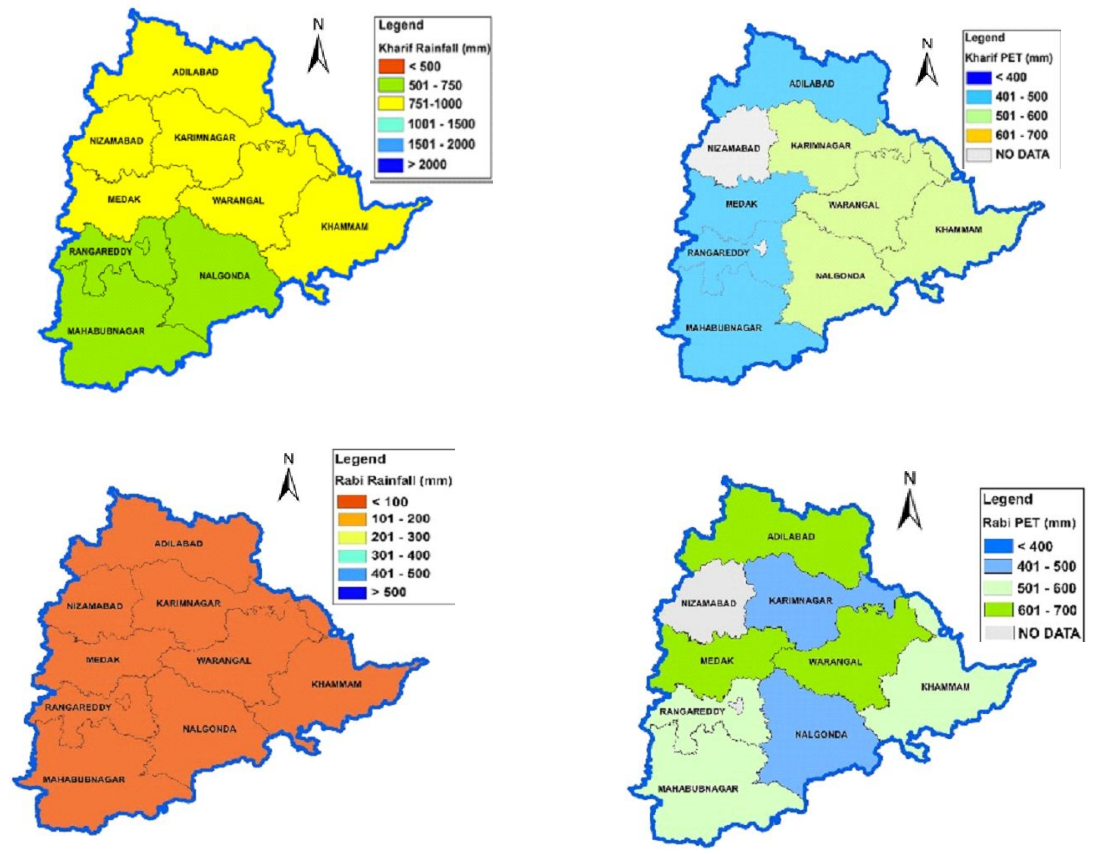

Fig. 1: District wise rainfall and PET during kharif and rabi

\section{RESULTS AND DISCUSSION}

\section{Rainfall and evapotranspiration}

Southern districts receive less than $500 \mathrm{~mm}$ rainfall in kharif season whereas PET requirement normally exceeds causing rainfed agriculture and sustenance farming in these areas. Though irrigated agriculture also practiced in few pockets in these areas, nevertheless it based on groundwater over-exploitation. The northern part of the region experiences rainwater surplus over PET providing scope to cultivate water intensive crop during kharif with existing water resources available.

In general, all the area receives meager rainfall i.e. less than $100 \mathrm{~mm}$ during rabi season. Despite variation in rainfall and PET, water deficit conditions prevailing in all districts in rabi season. These situations resulted into limited farming activities during rabi season and lead to exploitation of ground water in rainfed and irrigated area respectively. The district wise variation in PET and rainfall are presented in Fig. 1. 
Table 4 : Existing and proposed cropping pattern - Kharif season (Area in ,000 ha)

\begin{tabular}{|c|c|c|c|c|c|c|c|c|c|c|c|c|}
\hline \multirow[t]{2}{*}{ District } & \multicolumn{4}{|c|}{ Primary crop } & \multicolumn{4}{|c|}{ Secondary crop } & \multicolumn{4}{|c|}{ Tertiary crop } \\
\hline & Rainfed & Area & Irrigated & Area & Rainfed & Area & Irrigated & Area & Rainfed & Area & Irrigated & Area \\
\hline \multicolumn{13}{|l|}{ Existing } \\
\hline Adilabad & Cotton & 292 & Paddy & 20 & Soyabean & 120 & $\ldots$ & 0 & Redgram & 53 & $\ldots$ & 0 \\
\hline Karimnagar & Cotton & 62 & Paddy & 126.6 & $\ldots$ & 0 & Maize & 106 & $\ldots$ & 0 & Cotton & 42 \\
\hline Khammam & Cotton & 98.5 & Paddy & 150 & Maize & 16 & Maize & 30 & Mung & 21 & Cotton & 20 \\
\hline Mahbubnagar & Paddy & 181 & Castor & 139 & $\ldots$ & 0 & Maize & 113 & $\ldots$ & 0 & Redgram & 66 \\
\hline Medak & Paddy & 62 & Maize & 103 & Sugarcane & 28 & Mung & 48 & Sunflower & 2 & Jowar & 26 \\
\hline Nalgonda & Paddy & 163 & Cotton & 106.2 & Mung & 43.9 & Castor & 39.4 & $\ldots$ & 0 & Redgram & 37.5 \\
\hline Rangareddy & Paddy & 18 & Redgram & 29.7 & $\ldots$ & 0 & Maize & 20.8 & $\ldots$ & 0 & Cotton & 16.2 \\
\hline Warangal & Paddy & 107 & Cotton & 95 & Cotton & 63 & Maize & 41 & Chillies & 14 & Redgram & 21 \\
\hline \multicolumn{13}{|c|}{ Proposed for Scenario A } \\
\hline Adilabad & Cotton & 150 & Paddy & 10 & Soyabean & 160 & $\ldots$ & 0 & Redgram & 165 & $\ldots$ & 0 \\
\hline Karimnagar & Cotton & 38 & Paddy & 5 & $\ldots$ & 0 & Maize & 262 & $\ldots$ & 0 & Cotton & 32 \\
\hline Khammam & Cotton & 79 & Paddy & 30 & Maize & 86 & Maize & 80 & Mung & 41 & Cotton & 20 \\
\hline Mahbubnagar & Paddy & 81 & Castor & 139 & $\ldots$ & 0 & Maize & 113 & $\ldots$ & 0 & Redgram & 166 \\
\hline Medak & Paddy & 32 & Maize & 103 & Sugarcane & 8 & Mung & 48 & Sunflower & 2 & Jowar & 76 \\
\hline Nalgonda & Paddy & 83 & Cotton & 106 & Mung & 94 & Castor & 40 & $\ldots$ & 0 & Redgram & 67 \\
\hline Rangareddy & Paddy & 5 & Redgram & 50 & $\ldots$ & 0 & Maize & 20 & $\ldots$ & 0 & Cotton & 10 \\
\hline Warangal & Paddy & 47 & Cotton & 45 & Cotton & 63 & Maize & 61 & Chillies & 64 & Redgram & 61 \\
\hline \multicolumn{13}{|c|}{ Proposed for Scenario B } \\
\hline Adilabad & Cotton & 30 & Paddy & 5 & Soyabean & 150 & $\ldots$ & 0 & Redgram & 300 & $\ldots$ & 0 \\
\hline Karimnagar & Cotton & 30 & Paddy & 5 & Sorghum & 168 & Maize & 102 & $\ldots$ & 0 & Cotton & 32 \\
\hline Khammam & Cotton & 30 & Paddy & 20 & Maize & 70 & Maize & 30 & Mung & 166 & Cotton & 20 \\
\hline Mahbubnagar & Paddy & 20 & Castor & 170 & $\ldots$ & 0 & Maize & 63 & $\ldots$ & 0 & Redgram & 246 \\
\hline Medak & Paddy & 20 & Maize & 23 & Sugarcane & 8 & Mung & 100 & Sunflower & 2 & Jowar & 116 \\
\hline Nalgonda & Paddy & 33 & Cotton & 50 & Mung & 144 & Castor & 56 & $\ldots$ & 0 & Redgram & 107 \\
\hline Rangareddy & Paddy & 3 & Redgram & 70 & $\ldots$ & 0 & Maize & 7 & $\ldots$ & 0 & Cotton & 5 \\
\hline Warangal & Paddy & 15 & Cotton & 30 & Cotton & 38 & Maize & 30 & Chillies & 74 & Redgram & 162 \\
\hline
\end{tabular}

\section{Cropping system}

\section{Prevailing cropping system in Kharif season}

$80 \%$ of the cultivationarea in almost all the districts is coveredby single predominant crop indicating mono-crop farming system which is highly vulnerable in climatic aberrant conditions. Paddy, cotton and groundnut are major predominant kharif crop in the region followed by pulse crops. The district wise predominant rainfed kharif crops area are presented in Table 4 and 5.

Unlike rainfed conditions, transplanted paddy is the sole crop that cover $60 \%$ of the irrigated area for which groundwater is the major source. This true to the districts of Adilabad, Karimnagar and Khammam. However, irrigated maize and cotton are prevailed in few districts where irrigated area is less than $30 \%$. There are other irrigated crops including pulses, oilseeds and fodder are practiced to substantiate transplanted paddy at limited scale. The district-wise distribution of predominant irrigated kharif crop is presented in Table 4.

\section{Prevailing cropping system in rabi season}

In rabi season, limited area is under cultivation due to inadequate rains. The rainfed crops of rabi season include 
Table 5:Existing and proposed Cropping Pattern- Rabi Season (Area in ,000 ha)

\begin{tabular}{|c|c|c|c|c|c|c|c|c|c|c|c|c|}
\hline \multirow[t]{2}{*}{ District } & \multicolumn{4}{|c|}{ Primary crop } & \multicolumn{4}{|c|}{ Secondary crop } & \multicolumn{4}{|c|}{ Tertiary crop } \\
\hline & Rainfed & Area & Irrigated & Area & Rainfed & Area & Irrigated & Area & Rainfed & Area & Irrigated & Area \\
\hline Adilabad & Jowar & 29 & Redgram & 9 & Bengalgram & 27 & Paddy & 8.9 & $\ldots$ & 0 & Wheat & 4 \\
\hline Karimnagar & $\ldots$ & 0 & Paddy & 84.2 & $\ldots$ & 0 & Maize & 45.6 & $\ldots$ & 0 & Mung & 1.6 \\
\hline Khammam & Maize & 10 & Paddy & 32 & Greengram & 5 & Maize & 11 & Redgram & 0.8 & $\ldots$ & 0 \\
\hline Mahbubnagar & Maize & 280 & Jowar & 20 & Groundnut & 54 & $\ldots$ & 0 & Paddy & 42 & $\ldots$ & 0 \\
\hline Medak & Paddy & 31 & Bengalgram & 36 & Sunflower & 14 & Jowar & 23 & Maize & 3 & Sunflower & 8.2 \\
\hline Nalgonda & Paddy & 147.7 & $\ldots$ & 0 & Groundnut & 16.6 & $\ldots$ & 0 & $\ldots$ & 0 & $\ldots$ & 0 \\
\hline $\begin{array}{l}\text { Rangareddy } \\
6.7\end{array}$ & Paddy & 12.1 & Chickpea & 7.4 & $\ldots$ & 0 & \multicolumn{2}{|c|}{ Groundnut } & 6.8 & $\ldots$ & 0 & Jowar \\
\hline Warangal & Bajra & 20 & Paddy & 14 & Jowar & 7 & Chilies & 3 & Mung & 2 & $\ldots$ & 0 \\
\hline \multicolumn{13}{|c|}{ Proposed for Scenario A } \\
\hline Adilabad & Jowar & 29 & Redgram & 9 & Bengalgram & 27 & Paddy & 9 & $\ldots$ & 0 & Wheat & 4 \\
\hline Karimnagar & $\ldots$ & 0 & Paddy & 54 & $\ldots$ & 0 & Maize & 46 & $\ldots$ & 0 & Mung & 32 \\
\hline Khammam & Maize & 10 & Paddy & 17 & Greengram & 8 & Maize & 16 & Redgram & 8 & $\cdots$ & 0 \\
\hline Mahbubnagar & Maize & 170 & Jowar & 115 & Groundnut & 104 & $\ldots$ & 0 & Paddy & 7 & $\ldots$ & 0 \\
\hline Medak & Paddy & 11 & Bengalgram & 46 & Sunflower & 14 & Jowar & 34 & Maize & 3 & Sunflower & 8 \\
\hline Nalgonda & Paddy & 88 & $\ldots$ & 0 & Groundnut & 77 & $\ldots$ & 0 & $\ldots$ & 0 & $\ldots$ & 0 \\
\hline $\begin{array}{l}\text { Rangareddy } \\
12\end{array}$ & Paddy & 5 & Chickpea & 8 & $\ldots$ & 0 & \multicolumn{2}{|c|}{ Groundnut } & 8 & $\ldots$ & 0 & Jowar \\
\hline Warangal & Bajra & 20 & Paddy & 6 & Jowar & 10 & Chilies & 7 & Mung & 3 & $\ldots$ & 0 \\
\hline \multicolumn{13}{|c|}{ Proposed for Scenario B } \\
\hline Adilabad & Jowar & 29 & Redgram & 9 & Bengalgram & 27 & Paddy & 9 & $\cdots$ & 0 & Wheat & 4 \\
\hline Karimnagar & $\ldots$ & 0 & Paddy & 34 & $\ldots$ & 0 & Maize & 26 & $\ldots$ & 0 & Mung & 72 \\
\hline Khammam & Maize & 10 & Paddy & 8 & Greengram & 15 & Maize & 6 & Redgram & 20 & $\ldots$ & 0 \\
\hline Mahbubnagar & Maize & 60 & Jowar & 267 & Groundnut & 64 & $\ldots$ & 0 & Paddy & 5 & $\ldots$ & 0 \\
\hline Medak & Paddy & 5 & Bengalgram & 52 & Sunflower & 14 & Jowar & 39 & Maize & 3 & Sunflower & 3 \\
\hline Nalgonda & Paddy & 38 & $\ldots$ & 0 & Groundnut & 127 & $\ldots$ & 0 & $\ldots$ & 0 & $\ldots$ & 0 \\
\hline Rangareddy & Paddy & 2 & Chickpea & 5 & $\ldots$ & 0 & Groundnut & 3 & $\ldots$ & 0 & Jowar & 23 \\
\hline Warangal & Bajra & 20 & Paddy & 6 & Jowar & 10 & Chilies & 7 & Mung & 3 & $\ldots$ & 0 \\
\hline
\end{tabular}

mostlypulses and fodder. The acreage of primarily dominating crops like Black gram, Bengal Gram and Green Gram are widely spread across the districts of the region.

The region, conventionally witnesses the cultivation of transplanted paddy in rabi season which, cover more than $50 \%$ of irrigated area. Various pulses and oilseeds are other most preferred crop for irrigated area in rabi season. The irrigated area in this season exhibits crop diversification to some extent. However, paddy still preferred but is lesserintensive as compared to otherkharif.The details of cropping system for rabi season is presented in Table 5.

Proposed cropping system for kharif season-Scenario A

The macro-level analysis suggested reducing significant area of paddy and cotton under both rainfed and irrigated condition. This would provide the scope to increase the acreage of maize, redgram and Mung substantially, from 16 to 86,53 to 165 and 65 to 135 thousand ha, respectively. Therefore, significant changes in area under different crops of existing cropping system were suggested in these districts for better water saving and more crop diversity. The change 
Table 6: Economic analysis of various scenarios

\begin{tabular}{|c|c|c|c|c|c|c|}
\hline \multirow[t]{2}{*}{ District } & \multicolumn{3}{|c|}{ Kharif } & \multicolumn{3}{|c|}{ RabiIn crore Rs. } \\
\hline & Cost & Return & B:C Ratio & Cost & Return & B:C Ratio \\
\hline Adilabad & 214.37 & 338.17 & 1.58 & 24.74 & 71.74 & 2.90 \\
\hline Karimnagar & 142.84 & 357.6 & 2.50 & 49.6 & 146.84 & 2.96 \\
\hline Khammam & 143.41 & 311.305 & 2.17 & 21.17 & 57.85 & 2.73 \\
\hline Mahbubnagar & 167.35 & 417.05 & 2.49 & 141.1 & 251.92 & 1.79 \\
\hline Medak & 100.4 & 333.5 & 3.32 & 37.04 & 99.02 & 2.67 \\
\hline Nalgonda & 152.675 & 312.057 & 2.04 & 66.85 & 71.98 & 1.08 \\
\hline Rangareddy & 32.821 & 95.631 & 2.91 & 12.08 & 28.61 & 2.37 \\
\hline Warangal & 152.49 & 309.41 & 2.03 & 16.39 & 38.51 & 2.35 \\
\hline Overall & 1098.356 & 2474.723 & 2.25 & 360.64 & 754.95 & 2.09 \\
\hline \multicolumn{7}{|l|}{ Scenario A } \\
\hline Adilabad & 181.05 & 337.95 & 1.87 & 24.74 & 71.74 & 2.90 \\
\hline Karimnagar & 128.88 & 413.86 & 3.21 & 43 & 148.64 & 3.46 \\
\hline Khammam & 129.28 & 302.15 & 2.34 & 19.72 & 57.74 & 2.93 \\
\hline Mahbubnagar & 160.35 & 526.05 & 3.28 & 135 & 373.77 & 2.77 \\
\hline Medak & 82.4 & 311.8 & 3.78 & 35.18 & 116.97 & 3.32 \\
\hline Nalgonda & 139.47 & 379.37 & 2.72 & 69.85 & 116.38 & 1.67 \\
\hline Rangareddy & 30.7 & 112.2 & 3.65 & 11.28 & 35.36 & 3.13 \\
\hline Warangal & 133.99 & 434.71 & 3.24 & 15.09 & 43.48 & 2.88 \\
\hline Overall & 986.12 & 2818.09 & 2.86 & 348.5 & 952.56 & 2.73 \\
\hline \multicolumn{7}{|l|}{ Scenario B } \\
\hline Adilabad & 156.2 & 342.2 & 2.19 & 24.74 & 71.74 & 2.90 \\
\hline Karimnagar & 110.48 & 326.5 & 2.96 & 35.4 & 144.64 & 4.09 \\
\hline Khammam & 98.88 & 316.36 & 3.20 & 17.94 & 51.72 & 2.88 \\
\hline Mahbubnagar & 160.35 & 526.05 & 3.28 & 135 & 373.77 & 2.77 \\
\hline Medak & 69.36 & 303 & 4.37 & 35.18 & 116.97 & 3.32 \\
\hline Nalgonda & 115.43 & 420.29 & 3.64 & 72.35 & 153.38 & 2.12 \\
\hline Rangareddy & 30.7 & 112.2 & 3.65 & 11.28 & 35.36 & 3.13 \\
\hline Warangal & 133.58 & 518.22 & 3.88 & 15.09 & 43.48 & 2.88 \\
\hline Overall & 874.98 & 2864.82 & 3.27 & 341.62 & 979.54 & 2.87 \\
\hline
\end{tabular}

includes prominence of other oilseed and pulse crops in existing cropping system. The district-wise allocation of area under different rainfed crop for this scenario is presented in Table4.

\section{Proposed cropping system for rabi season - Scenario A}

The existing cropping system in the Adilabad district havingcomposite crop coefficient, $\mathrm{K}$, less than the threshold value of 0.65 and thus no change in the existing cropping system is suggested. The area under rainfedmaize and paddy

is suggested to reduce to 183 and 111 thousand Ha from 293 and 233thousand $\mathrm{Ha}$, respectively. This provides the scope to substantially increasethe area under rainfed sorghum and groundnut. Substantial area can be put under irrigated sorghum by reducing the acreage of paddy. It is suggested to reduce the area under transplanted paddy by $50 \%$ to enhance water productivity and crop diversity. By this preposition $33 \%$ additional area can be irrigated from the existing resources. The district-wise allocation of area under 
different irrigated crop for this scenario is presented in Table5.

\section{Proposed cropping system for kharif season-Scenario B}

Scenario B explores the potential to reduce the water requirement by $20 \%$ through change in existing cropping system. Area under rainfed paddy under this scenario may bereduce to111 thousand Ha. The analysis suggested for comprehensive area under pulses such as redgram and Mungin 300 and 310 thousand ha, respectively could be realized.This scenario allows more crop diversity as area under other crops including millets and Sorghum, could be increased substantially.In this scenario, additional 233 thousand Ha area could be brought under irrigation from the existing resources. The detailed analysis for this scenario is presented in Table 4.

\section{Proposed cropping system for rabi season - Scenario B}

In most of the districts, this scenario is not feasible since the composite crop coefficient is less than the threshold except Karimnagar, Khammam and Nalgonda district. For those districts where this scenario holds good, pulses may be recommended to practices on rainfed area substantially. In this scenario, rainfed Sorghum in 168 thousand ha and Mung in 144 thousand ha can be introduced in Karimnagar and Nalgonda district respectively. The proposed area allocation for different crop under this scenario is presented in Table 5.

It is understood that future food production needs of the world would come from rainfed system which spread over several agro-ecological regions and mostly characterized as low productive and non-remunerative. Rainfed agriculture is most prominent in arid, semi-arid and sub-humid regions of Indian subcontinents vis a vis many parts of world including sub-Saharan Africa, Latin America and South Asia. The major ecological and economic factors that make agriculture unsustainable in Indian sub-continent, includes rainfed cultivation, small and fractured land holdings, insufficient crop yield and limited scope to adopt intensive agriculture. However, the water availability and requirement are not the exclusive basis for cultivating these crops. There are many other determinants that defined the traditional farming and those are socio-economic, livelihood, market surplus and employment which also affect the choice of crops during the season. The farming practice also determined by the broader objective of livelihood security and agricultural productivity. Nonetheless agricultural water requirement assumes major importance in agricultural productivity in view of the global challenge of future water scarcity for agriculture.

There is a need to arrive at equilibrium between cropping system (based on prevailing socio-economic and cultural tradition) and its implication on available water resources. In the present study, most of the irrigated paddy area utilizes ground water extensively that exploited the groundwater to the danger zone. But, at the same time other local socio-economic conditions and cultural traditions cannot be ignored completely. Thus,majority of local farmers would be reluctant to adopt comprehensive changes in existing cropping system for sole reason of water productivity. However, more than 20 different crops are cultivated in the region at various extent and magnitude and if changes suggested within the framework of these crops at lower scale, there would be scope for adaptation. Thus, new crop and area were recommended at limited level so that it would easily adapted by the local farmers.

\section{Economic analysis}

The various economic parameters were computed for existing and scenario $\mathrm{A}$ and $\mathrm{B}$ for both the season i.e. kharif and $\mathrm{rabi}$ and is presented in table 6. In case of existing cropping system, the $\mathrm{B}: \mathrm{C}$ ratio varies from 1.58 (Adilabad district) to 2.91 (Rangareddy District) and 1.08 (Nalgonda district) to 2.96 (Karimnagar district) for kharif and rabi season respectively. Overall B:C ratio was computed as 2.25 and 2.09 for kharif and rabi season, respectively. The economics improves significantly in scenario A where it computed as 2.86 and 2.73 , respectively. The economical return further improves in the scenario B to 3.27 and 2.87 for kharif and rabi, respectively.

\section{CONCLUSION}

The existing cropping system prevailing in the state of Telangana was evaluated to improve water productivity and crop diversityfor better economical return and livelihood security. The agriculture in major part of the region is found to be dominate by transplanted paddy which leads to monocropping and excessive exploitation of ground water which is true for both the season. Considering the large-scale agricultural productivity an issue, re-appropriation was quantified for area under various crops and was based on composite crop coefficient under two scenarios i.e. $10 \%$ and $20 \%$ reduction in water requirementcoupled with existing water resources available. The study also envisages the possibility of introduction of new crops such as millet and sorghum at macro level. Most of the analysis indicates the increase in area under pulses and millets in respect to 
transplanted paddy. The economic analysis suggested that not only the water productivity but also $B$ : $C$ ratio could be enhanced significantly under the envisaged scenarios. The government of Telangana also promoting market led agricultural production system. The present findings based on objectives of water productivity and economical return, would certainly substantiate the initiative of market led agricultural production. Additionally, it is particularly important as these substitutions have the potential to bring nutritional security along with food security in the region. The recommendation thus found could be helpful to the policy makers and implementers who are active in agricultural production and input management at bigger scale.

\section{REFERENCES}

Trabucco,A., Zomer, R.J., Bossio, D.A., Straaten, O.V. and Verchot, L.V. (2008). Climate change mitigation through afforestation/ reforestation: A global analysis of hydrologic impacts with four case studies. Agric. Ecosys. Environ.,126 (1-2):81-97

Bastakoti, C.R., Prathapar, S.A. and Okwany, O.R. (2016).Community pond rehabilitation to deal with climate variability: A case study in Nepal Terai. Water Resour. Rural Develop., 7: 2035.

SrinivasaRao, Ch., Lal, R., Prasad, J.V.N.S., Gopinath, K.A., Singh, R., Jakkula,V.S., Sahrawatjj, K.L., Venkateswarlu, B., Sikka, A.K. and Virmani, S.M. (2015). Potential and challenges of rainfed farming in India. Adv. Agron., 133: 113-181

Cooper, P.J.M., Dimes J., Rao, KPC, Shapiro, B, Shiferaw, B and Twomlow S. (2008). Coping better with current climatic variabilityin the rain-fed farming systems of sub-Saharan Africa:Anessential first step in adapting to future climate change? Agric. Eco. Environ., 126: 24-35

Gupta, A.K., Tyagi, P. and Sehgal, V.K. (2011). Drought disaster challenges and mitigation in India: strategic appraisal. Current Sci., 100(12): 1795-1806.

Hargreaves, G.L., Hargreaves, G.H. and Riley, J.P. (1985). Irrigation water requirements for Senegal river basin. $J$. Irrig. Drain. Engg., 3: 265-275

Doninck, J.V., Baets, B.De., Peters, J., Hendrickx, G., Ducheyne, E. and Verhoest, N.E.C. (2014). Modelling the spatial distribution of culicoidesimicola: climatic versus remote sensing data. Remote Sens., 6: 6604-6619:

Kadiyala, M.D.M., Jones, J.W., Mylavarapu, R.S., Li, Y.C.,
Reddy, M.D. and Umadevi, M. (2015). Study of spatial water requirements of rice under various crop establishment methods using GIS and crop models. $J$. Agrometeorol., 17(1): 1-10.

Jones, P.G. and Thornton, P.K. (2013). Generating downscaled weather data from asuite of climate models for agricultural modelling applications. Agric. Sys., 114: 1-5

Pramod, V.P., Bapuji Rao, B., Ramakrishna, S.S.V.S., Sandeep, V.M., Patel, N. R., Sarathi, M.A., Sarath Chandran, Rao, V.U.M., ChowdharySanthibhushan P., and Vijayakumar, P. (2018). Trends in water requirements of wheat crop under projected climates in India. J. Agrometeorol., 20(2): 110-116

Rama Rao, C.A., Raju, B.M.K., Subba Rao, A.V.M., Rao, K.V., Rao, V.U.M., Ramachandran, K., Venkateswarlu, B. and Sikka,A.K.(2013). “ATLAS on vulnerability of Indian agriculture to climate change”ICAR-CRIDA, Hyderabad

Rao, A.S. and Poonia, S. (2011). Climate change impact on crop water requirements in arid Rajasthan.J. Agrometeorol., 13(1): 17-24.

Rao, B.K. and Rajput, T.B.S (2009)Decision support system for Efficient Water Management in Canal Command areas. Current Sci., 97(1): 90-98

Reddy, K.S., Kumar, M., Maruthi, V., Umesha, B., Vijayalaxmi and Rao, C.V.K.N. (2015). Dynamics of well irrigation systems and $\mathrm{CO}_{2}$ emissions in different agro-ecosystems of south-central India. Current Sci., 108(11): 20632070 .

Robert J. Zomer, Antonio Trabucco, Deborah A. Bossio, Louis V. Verchot (2008). Climate change mitigation:A spatial analysis of global land suitability for clean development mechanism afforestation and reforestation. Agric., Eco. Environ., 126(1-2):67-80

Rodrigo W. Soria-Auza, Michael Kessler, Kerstin Bach, Paola M. Barajas-Barbosa, Marcus Lehnert, SebastianK. Herzo and Jürgen Böhner. (2010). Impact of the quality of climate models for modelling species occurrences in countries with poor climatic documentation: a case study from Bolivia. Ecol. Model., 221: 1221-1229

Sharma, K.D. (2011). Rainfed agriculture could meet the challenge of food security in India. Current Sci., 100(11):1615-1616

Singh, Gaurav, Dinesh, D., Kakade, V.D., Bhatnagar, P.R. and Pande, V.C. (2019). Precipitation probabilityand water budgeting for crop planning in central Gujarat. $J$. Agrometeorol., 21(3): 392-396 
SrinivasaRao, Ch., RavindraChary, G., Mishra, P.K., Subba Reddy, G., MaruthiSankar, G.R., Venkateswarlu, B. and Sikka,A.K. (2014). "Rainfed Farming-ACompendium of Doable Technologies"ICAR-CRIDA, Hyderabad

Virmani SM., Pathak, P. and Singh, R, (1991). Soil related constraints in dryland crop production in Vertisols, Alfisols andEntisols of India. In:"Soil Related Constraints in Crop Production" Bulletin 15, Indian Society of Soil Science: pp:80-95

Yusuf Yigini and PanosPanagos(2016) Assessment of soil organic carbon stocks under future climate and land cover changes in Europe.Sci. Total Environ., 1: 838850

Zade, M., Ray, S.S., Dutta, S. and Panigrahy, S. (2005). Analysis of runoff pattern for all major basins of India derived using remote sensing data. Current Sci., 88(8): 13011305

Zomer R.J., Bossio D.A., Trabucco A., Yuanjie L., Gupta D.C. and Singh V.P. (2007). "Trees and water: smallholder agro-forestry on irrigated lands in northern India." IWMI Research Report, 122: pp:45 